\title{
Interaksi Komunikasi Kelompok terhadap Penghuni Panti Werdha Milenia Jakarta Utara
}

\author{
Carlos Natalius, Diah Ayu Candraningrum \\ carlos.915150026@stu.untar.ac.id,diahc@fikom.untar.ac.id
}

Fakultas Ilmu Komunikasi Universitas Tarumanagara

\begin{abstract}
Interact with another individual is very important, because in a relationship communicate, start with interact brand first, either individually or in groups, for example in a group who are the elderly and the from the institution, consisting of several to live in it, and is divided into several groups that have a purpose and influence of other components.A theory that used as basis in this research is social interaction introduced by walgito in 2007 and communication group introduced by wiryanto (2005). The kind of research this is qualitative research was conducted descriptive in nature, with the approach the case studies. The contents of the research is to show how the interaction of the inmates of the group with clusters of the elderly and the other from the institution
\end{abstract}

Keywords: Keywords: Interaction, Groups, Nursing Home

\begin{abstract}
Abstrak
Berinteraksi dengan individu lain sangat penting dalam sebuah hubungan komunikasi. Komunikasi dimulai dengan interaksi terlebih dahulu, baik secara individu maupun kelompok. Dalam kelompok di panti jompo, terdiri dari beberapa penghuni di dalamnya, dan terbagi menjadi beberapa kelompok yang memiliki tujuan dan mempengaruhi kelompok lainnya. Teori yang dijadikan landasan dalam penelitian ini adalah Interaksi Sosial yang diperkenalkan oleh Walgito dan komunikasi kelompok yang diperkenalkan oleh Wiryanto. Jenis penelitian ini adalah metode penelitian kualitatif bersifat deskriptif, dengan pendekatan studi kasus. Isi dalam penelitian ini adalah untuk menunjukkan bagaimana interaksi kelompok para penghuni dengan kelompok lainnya di panti jompo.
\end{abstract}

Kata Kunci: Interaksi, Kelompok, Panti Jompo

\section{Pendahuluan}

Manusia merupakan makhluk berakal budi yang tidak lepas dari kegiatan berpikir. Dalam keadaan seorang diri, manusia berpikir tentang apa yang akan dibicarakan dan dikerjakan besok atau kelak ketika bertemu dengan situasi dan kondisi tertentu. Ketika berjumpa dengan orang lain, manusia terus berpikir dan mengomunikasikan hasil pikirannya. Bisa saja, kedua belah pihak saling diam, tetapi dalam benaknya tetap saja berpikir atau berkata-kata.

Faktor yang sangat penting dalam proses komunikasi adalah bahasa. Bahasa merupakan alat komunikasi yang digunakan untuk berinteraksi antar sesama manusia. Bahasa dan komunikasi juga memiliki hubungan yang sangat erat dalam kehidupan, karena tanpa bahasa manusia tidak dapat melakukan interaksi dengan baik terhadap orang lain. Bahasa terbagi menjadi dua ragam, yakni ragam lisan dan ragam tulis. Dalam berbahasa lisan, manusia dapat langsung berkomunikasi bertatap muka, 
sedangkan bahasa tulis, manusia dapat berkomunikasi dengan surat menyurat (Aris \& Supriyadi, 2016).

Interaksi sosial bisa terjadi kapan saja dan di mana saja. Tidak lepas juga interaksi sosial yang ada di panti jompo, walaupun di dalamnya para penghuni yang sudah menua (lansia). Proses menua bukanlah suatu penyakit tetapi suatu proses alamiah. Poses menua sulit dihindari dengan upaya apapun, namun manusia dapat berusaha memperlambat proses alami ini dan menjaga supaya sampai usia lanjut masih bisa hidup dalam keadaan sehat dan menikmati kehidupan yang bahagia dan berkualitas (Hardywinoto \& Setiabudi, 1999). Secara individu, pengaruh proses menua dapat menimbulkan berbagai masalah baik secara fisik - biologik, mental, hubungan sosial dan ekonomi. Proses menua ini mempengaruhi kualitas hidup lansia.

Komponen dari kualitas hidup salah satunya adalah kepuasan hidup. Kepuasan hidup berorientasi ada proses pengalaman masa lalu dan masa kini. Jika di masa tua lansia memiliki perilaku murung, suka menyendiri, terisolasi dari kegiatan di luar rumah, ada kemungkinan bahwa mereka masih memiliki kebutuhan di masa lalu yang belum dipuaskan. Kualitas hidup merupakan satu komponen utama yang bersifat subyektif untuk kesejahteraan hidup manusia. Kualitas hidup digunakan secara luas sebagai indeks kesejahteraan psikologis pada orang - orang dewasa lanjut, ada banyak hal yang dapat menciptakan munculnya kepuasan akan hidup pada lansia. Kualitas hidup pada lansia dapat terbentuk apabila lansia mampu menyelesaikan tugas - tugas perkembangan. Adapun tugas perkembangan lansia adalah menyesuaikan diri dengan kematian pasangan hidup, membentuk hubungan dengan orang lain yang seusia dan menyesuaikan diri dengan peran sosial secara luwes (Diener, 1998).

Searah dengan pertambahan usia, mereka akan mengalami degeneratif baik dari segi fisik maupun segi mental. Akibat dari pertambahan usia mereka adalah menurunnya derajat kesehatan, kehilangan pekerjaan, dianggap sebagai individu yang tak mampu, akan mengakibatkan orang lanjut usia secara perlahan menarik diri dari hubungan dengan masyarakat sekitar. Hal ini dapat mempengaruhi interaksi sosial lansia tersebut (Hardywinoto \& Setiabudi, 2005).

Menurut informasi yang disampaikan oleh Kementrian Kesehatan Republik Indonesia, seseorang dapat dikatakan menjadi lansia ketika sudah menginjakkan umur 60 tahun. Jumlah lansia di Indonesia pada tahun 2000 diproyeksikan sebesar 7,28\% dan mengalami peningkatan pada tahun 2020 menjadi sebesar 11,34\%. Ketika para lansia tidak lagi mendapat rasa kepedulian dari anggota keluarganya, terjadilah peningkatan angka terhadap jumlah penghuni panti jompo. Anggota keluarga yang tidak ingin direpotkan dengan kehadiran para lansia seringkali menyarankan agar mereka tinggal di panti jompo (Rifa, 2014).

\section{Metode Penelitian}

Pendekatan penelitian yang digunakan penulis yaitu pendekatan kualitatif deskriptif. Menurut Darmadi (2013:153), metode penelitian yaitu cara ilmiah untuk mendapatkan data dengan tujuan kegunaan tertentu. Cara ilmiah berarti kegiatan penelitian itu didasarkan pada ciri - ciri keilmuan yaitu sistematis, rasional dan empiris.

Menurut Creswell (2010: 20), studi kasus yaitu strategi penelitian di mana di dalamnya peneliti menyelidiki secara cermat suatu program peristiwa, aktivitas, proses atau sekelompok individu. Studi kasus merupakan sebuah penyelidikan empiris yang menginvestigasi fenomena kontemporer dalam konteks kehidupan, khususnya ketika batas antara fenomena dan konteks tidak begitu jelas (Yin 2011: 1). 
Subjek penelitian dalam penelitian ini yaitu lima orangtua yang tinggal di panti jompo dan pengurus panti jompo. Kriteria subyek yakni penghuni panti jompo (lansia), masih bisa berinteraksi dengan penghuni lain secara berkelompok. Permasalahan yang diangkat yaitu bagaimana interaksi komunikasi kelompok para penghuni panti jompo.

Objek penelitian yaitu interaksi komunikasi kelompok para penghuni panti jompo di Melania Pademangan Jakarta Utara. Data primer yaitu data yang ditujukan untuk informasi, yang diperoleh dari peneliti yang berkaitan dengan variabel minat untuk tujuan studi yang spesifik. Sumber data primer yaitu responden individu, kelompok fokus, internet juga dapat menjadi sumber data primer jika kuisioner disebarkan melalui internet (Sekaran, 2011), yaitu observasi dan wawancara. Data sekunder adalah data yang mengacu pada informasi yang dikumpulkan dari sumber yang telah ada. Sumber data sekunder adalah publikasi pemerintah, analisis industri oleh media, situs Web, internet dan lainnya (Sekaran, 2011) yaitu studi pustaka dan penelusuran data online

Teknik analisis data adalah proses menurutkan kategori data, lalu mengumpulkan ke dalam sebuah pola, kategori dan satuan uraian dasar. Membedakannya yaitu dengan penafsiran, memberikan arti yang signifikan terhadap analisis, menjelaskan pola uraian dan mencari hubungan di antara dimensi - dimensi uraian (Moleong 2010:280).

Dalam pengecekan data, peneliti menggunakan teknik pemeriksaan keabsahan data yaitu triangulasi. Triangulasi merupakan teknik pemeriksaan keabsahan data yang memanfaatkan sesuatu yang lain. Di luar data itu untuk keperluan pengecekan atau pembanding terhadap data itu (Moleong 2010: 330).

\section{Hasil Temuan dan Diskusi}

\section{a. Interaksi Sosial}

Komunikasi penghuni panti jompo dengan penghuni lainnya dalam sebuah kelompok atau lebih dari tiga orang disebut interaksi sosial dalam komunikasi kelompok. Sebuah hubungan didalamnya pasti ada para komunikator yang saling berinteraksi. Namun sebelum itu, terdapat sebuah pertemuan antara individu maupun dengan kelompok. Kemudian ada timbal balik dan tidak selalu baik, namun ada yang buruk seperti yang diungkapkan oleh Oma Fenny yang pertama kali bertemu dan berinteraksi dengan Oma Alan dan Oma Opung. Responden bercerita mengapa ia masuk ke panti dan berbicara tentang makanan dan tempat liburan (hasil wawancara dengan Oma Fenny pada tanggal 30 Mei 2019).

Hal ini juga diperkuat dengan perkataan Oma Alan sebagai lawan dari interaksi Oma Fenny, mengungkapkan bahwa ia sering sekali bercerita dengan Oma Fenny. Pertama kali berinteraksi dengan Oma Fenny bercerita tentang masa lalu mengapa ia bisa dititipkan di panti, dan berbicara soal makanan serta tempat yang sering dikunjungi sewaktu dulu (hasil observasi Oma Alan pada tanggal 30 Mei 2019).

Kemudian penulis melihat penghuni lainnya, mendatangi responden yang sedang berinteraksi yaitu Oma Opung. Responden datang dan berinteraksi dengan narasumber lainnya, sehingga membentuk sebuah interaksi dalam komunikasi kelompok, responden mengungkapkan bahwa responden juga ingin berinteraksi dengan penghuni lainnya, karena ia merasa sangat jenuh, tidak ada teman ngobrol karena kamar dia berjarak cukup jauh dari kamar Oma Fenny dan Oma Alan (hasil wawancara dengan Oma Opung pada tanggal 30 Mei 2019). 
Kemudian interaksi sosial selanjutnya juga dilakukan oleh Opa Kotiken dengan Oma Aihun. Kamar keduanya bersebelahan membuat mereka bisa berkomunikasi dengan mudah, ditambah mereka menggunakan bahasa Khek (bahasa Kalimantan keturunan orang Tionghoa), yang membuat mereka semakin erat dalam berinteraksi dan berhubungan (hasil wawancara dengan Opa Kotiken pada tanggal 30 Mei 2019).

Hal ini juga di perkuat dari pernyataan Oma Aihun, bahwa responden juga senang berinteraksi dengan Opa Kotiken karena, responden kurang bisa bahasa Indonesia. (hasil wawancara dengan Oma Aihun pada tanggal 30 Mei 2019)

\section{b. Aspek Kontak Sosial}

Dalam setiap hubungan interaksi didalamnya ada kontak sosial yang positif dan negatif, seperti Oma Aihun yang memiliki kontak sosial positif dengan penghuni lainnya, yaitu responden tidak pernah konflik dengan penghuni lain, responden berkomunikasi dengan baik, lalu dengan gerakan tubuh yaitu senyum (hasil wawancara dengan Oma Aihun pada tanggal 30 Mei 2019).

Kemudian hal ini juga diungkapkan oleh Oma Opung yang berinteraksi didalamnya ada kontak sosial yang negative. Responden sering terjadi konflik dengan penghuni lainnya yang sekamar. Konflik itu terjadi karena penghuni lainnya yang sekamar sangat berisik di malam hari dan membuat responden tidak bisa tidur di malam hari (hasil wawancara dengan Oma Opung pada tanggal 30 Mei 2019).

Kemudian interaksi kontak sosial yang negatif terjadi juga pada Oma Fenny. Responden mengungkapkan bahwa responden kesal karena celananya tertukar dengan penghuni lain, dan responden langsung melihat celananya di pakai oleh penghuni lain, dan responden langsung memarahi penghuni lain tersebut (hasil wawancara dengan Oma Fenny pada tanggal 30 Mei 2019).

Hal ini juga di dukung dengan perkataan Suster Aurel yaitu asisten atau pengurus Oma Fenny yang melihat kejadian tersebut. Responden mengungkapkan ia tertawa sedikit karena, Oma Fenny sewaktu memarahi penghuni lainnya sangat lucu, dan Suster Aurel segera menyuruh penghuni lainnya tersebut untuk melepaskan celananya dan mengembalikan ke pemiliknya. (hasil wawancara dengan Suster Aurel pada tanggal 30 Mei 2019).

\section{c. Aspek Komunikasi}

Dalam sebuah hubungan komunikasi, didalamnya ada interaksi sosial yang menyampaikan informasi, ide, pengetahuan kepada sesama, tentu ide dan pengetahuan itu tergantung dari individu itu sendiri dan ada timbal balik dari lawan bicaranya dengan maksud ke arah yang positif, seperti yang di ungkapkan Oma Fenny terhadap Oma Alan, responden sebelumnya tidak sekamar atau seruang dengan Oma Alan, kemudian responden berinteraksi dengan menyampaikan idenya untuk Oma Alan tidur sekamar dengan responden dengan maksud agar mereka bisa berinteraksi lebih dekat (hasil wawancara dengan Oma Fenny pada tanggal 30 Mei 2019).

Hal ini juga diperkuat dengan penyataan dari Oma Alan, yang mengungkapkan responden diminta Oma Fenny untuk tidur di kamar Oma Fenny, dengan alasan kamar responden berisik sehingga dia berhasil pindah kamar dan bisa lebih dekat dalam berinteraksi dengan Oma Fenny (hasil wawancara dengan Oma Alan pada tanggal 30 Mei 2019). 
Carlos Natalius, Diah Ayu Candraningrum: Interaksi Komunikasi Kelompok terhadap Penghuni Panti Wedha Milenia Jakarta Utara

\section{d. Komunikasi Kelompok}

Dalam sebuah komunikasi kelompok terdiri dari beberapa orang atau komunikator yang berkomunikasi lebih dari tiga orang. Di dalam sebuah komunikasi kelompok juga terdapat hubungan interaksi dengan sesama anggota kelompok tersebut, dan di dalam kelompok tentu jumlah orang berbeda-beda dan memiliki tujuannya masing masing juga, dalam komunikasi kelompok terdapat primer dan sekunder, penulis lebih menekankan ke primer karena penelitian ini berfokus kepada kelompok yang berhubungan akrab, baik dan dekat di Panti Wreda Melania Jakata Utara.

Komunikasi kelompok terdiri dari tiga orang atau lebih dan memiliki tujuan. Tujuan dari setiap kelompok berbeda seperti diungkapkan oleh Oma Fenny bahwa di dalam kelompok mereka, terdapat Oma Alan, ditunjuk sebagai yang akan terus menyanyi dan menari di waktu sedang berkumpul bersama penghuni lain, untuk mencairkan suasana dari kejenuhan.

Pernyataan tersebut juga didukung oleh pernyataan Suster Aurel, yang mengungkapkan bahwa responden memang menunjuk salah satu orang dari perkumpulan kelompok di panti jompo ini. Pengelompokan terbagi menjadi tiga wilayah, ruang depan, tengah dan belakang yang membuat responden harus menunjuk salah satu dari setiap wilayah untuk mengambil peran dalam bernyanyi atau menari untuk mencairkan suasana di Panti Wreda.

\section{e. Kelompok primer bersifat dalam dan meluas}

Dalam sebuah hubungan komunikasi kelompok tentu kita mengungkapkan halhal yang bersifat pribadi baik verbal maupun non-verbal dengan kelompok lain, artinya kita bisa berkomunikasi secara langsung ataupun secara tidak langsung atau menggunakan bahasa tubuh, dalam sebuah komunikasi kelompok, seperti yang di ungkapkan oleh Oma Aihun. Responden berkomunikasi menggunakan bahasa khek dengan Opa Kotiken, dan mengungkapkan masalah pribadinya, responden juga mengungkapkan bagaimana ia menyapa penghuni dari kelompok lainnya (hasil wawancara dengan Oma Aihun pada tanggal 30 Mei 2019).

Opa Kotiken juga mengungkapkan bagaimana komunikasinya dengan kelompok lainnya. Responden selain berkomunikasi dengan Oma Aihun, responden juga sering berjalan ke kelompok yang berada di ruang belakang, karena di sana banyak penghuni yang bisa berbicara bahasa Khek, responden juga lancar dalam berbahasa Indonesia, jadi tidak ada kendala dalam berkomunikasi seperti yang dialami oleh Oma Aihun, responden juga mengungkapkan ia hanya senyum dan berjabat tangan dengan para penghuni yang berada di ruang tengah (hasil wawancara dengan Opa Kotiken pada tanggal 30 Mei 2019).

\section{f. Kelompok primer bersifat personal}

Dalam sebuah kelompok terdapat hubungan yang unik, sebagai contoh yaitu hubungan para penghuni panti, dan mereka pun memiliki peran masing - masing yaitu, seperti Oma Alan, di dalam kelompoknya responden berperan menjadi penghuni yang lucu, untuk menghibur teman kelompoknya dan kelompok lainnya (hasil wawancara dengan Oma Alan pada tanggal 30 Mei 2019)

Hal ini juga diperkuat dengan pernyataan Opa Kotiken yang memiliki peran yang sama dengan Oma Alan, yaitu ditunjuk sebagai penghuni yang lucu - lucuan, menari dan menyanyi untuk menghibur para penghuni lainnya, namun dia berada di 
kelompok ruang depan, berbeda dengan Oma Alan, yang berada di kelompok ruang tengah (hasil wawancara dengan Opa Kotiken pada tanggal 30 Mei 2019)

\section{g. Komunikasi primer lebih menekankan pada aspek hubungan}

Komunikasi dalam sebuah hubungan kelompok ada yang berhasil dan tidak. Keberhasilan dalam sebuah hubungan dikarenakan terus menjaga hubungan baik. Namun, tidak sedikit juga hubungan kelompok yang gagal seperti diungkapkan oleh Oma Opung. Dalam kelompoknya bagian depan, responden sering ngobrol dan berkomunikasi dengan penghuni kamar lainnya yang dekat dengan ruangannya. Namun sudah tidak berkomunikasi lagi karena penghuni tersebut sering marah dan berbicara dengan nada tinggi (hasil wawancara dengan Oma Opung pada tanggal 30 Mei 2019).

Berbeda dengan responden sebelumnya, Opa Kotiken berhasil dalam hubungan komunikasi dengan kelompok lainnya, yaitu kelompok ruang belakang maka dari itu responden suka berinteraksi dan berkomunikasi dengan ruang belakang. (Hasil Wawancara dengan Opa Kotiken pada tanggal 30 Mei 2019)

\section{h. Komunikasi primer lebih cenderung ekspresif}

Komunikasi dalam sebuah kelompok tentu memiliki tujuan, maksud dan gagasan terhadap lawan bicaranya, tentu setiap kelompok memiliki maksud dan tujuan yang berbeda, seperti yang diungkapkan oleh Oma Fenny yaitu maksud dan tujuan dari kelompoknya yaitu agar lebih nyaman dalam berkomunikasi dan bercerita dengan sesama kelompok (hasil wawancara dengan Oma Fenny pada tanggal 30 Mei 2019).

Suster Aurel mengatakan tujuan dan maksud responden dalam kelompok para suster, memiliki tujuan untuk merawat dan menjaga para penghuni untuk terus berhubungan baik (hasil wawancara dengan Suster Aurel pada tanggal 30 Mei 2019).

\section{i. Kelompok primer berkomunikasi lebih informal}

Dalam sebuah kelompok, mereka memiliki komunikasi dengan maksud dan tujuan. Komunikasi tersebut sebelumnya direncanakan atau resmi, walaupun yang direncanakan tidak semua sama, namun ada kelompok komunikasi yang tidak direncanakan ataupun tidak resmi seperti Opa Kotiken yang kelompoknya tidak direncanakan, maksud dan tujuannya juga hanya untuk mengisi waktu luang (hasil wawancara dengan Opa Kotiken pada tanggal 30 Mei 2019)

Kemudian Suster Aurel juga mengungkapkan bahwa responden dan teman kelompoknya yaitu, suster dan perawat yaitu kelompoknya di bentuk oleh yayasan, dan memiliki maksud dan tujuan yaitu, terus menjaga dan merawat para penghuni panti jompo (hasil wawancara dengan Suster Aurel pada tanggal 30 Mei 2019)

Penulis menggunakan teori komunikasi kelompok yang terdiri dari primer dan sekunder. Penulis lebih menekankan pada primer karena lebih menekankan pada aspek hubungan, dan memiliki keterkaitan dengan aspek lain, seperti meluas, personal, hubungan, ekspresif dan informal, komunikasi kelompok primer dengan berbagai aspek, berkaitan dengan interaksi sosial karena penulis meneliti interaksi kelompok komunikasi penghuni panti jompo.

Penulis memilih aspek yang bersifat meluas dan informal karena aspek tersebut yang lebih dominan. Pertama bersifat meluas karena hubungan dalam berkomunikasi, jika berhasil di dalam sebuah kelompok maka tujuan dan maksud dari kelompok tersebut pun akan berhasil juga. Kemudian informal, karena dalam sebuah kelompok tentu ada yang direncanakan, dan juga ada yang tidak, seperti para penghuni, 
kelompok mereka tidak direncanakan namun terbentuk dengan sendirinya karena interaksi mereka atau komunikasi mereka yang berhasil, berbeda dengan suster atau perawat di panti, mereka memang dibentuk dan ada maksud dan tujuan oleh si pembentuk kelompok mereka.

Kemudian keterkaitan interaksi sosial dan komunikasi kelompok yaitu, di dalam sebuah komunikasi kelompok di dalamnya terdiri dari beberapa orang yang saling berhubungan dan berkomunikasi, atau disebut sebagai pelaku komunikator, dan dalam sebuah komunikasi, di awali dengan sebuah interaksi antara individu atau kelompok.

\section{Simpulan}

Dalam berinteraksi dengan penghuni atau kelompok lainnya, harus ada dua aspek dalam interaksi sosial yaitu aspek kontak sosial dan aspek komunikasi, penghuni yang ingin berinteraksi dengan penghuni lainnya harus dengan kontak fisik dan simbolik, namun harus berhati - hati karena di dalamnya bisa terjadi hal yang negatif dan aspek komunikasinya yaitu penghuni menyampaikan idenya, pengetahuan dan maksud agar ada pengertian bersama dalam sebuah komunikasi kelompok.

Dalam sebuah kelompok yang terbentuk di panti jompo, membuat para komunikator yang berada didalamnya merasa nyaman, dikarenakan kelompok tersebut yang membuat suasana itu sendiri, dan didalam sebuah kelompok, di dalamnya terdapat kelompok lain, yang bisa saling mendukung dan kerja sama, namun tidak sedikit juga yang saling menjatuhkan atau membedakan dari kelompok satu dengan kelompok lainnya.

\section{Ucapan Terima Kasih}

Penulis mengucapkan terima kasih terutama kepada Tuhan Yang Maha Esa, kemudian kepada seluruh pihak yang telah membantu dan mendukung penulis selama proses penelitian ini berlangsung sampai penelitian ini selesai dan di publikasi.

\section{Daftar Pustaka}

Aris \& Supriyadi. (2016). Perspektif Pendidikan dan Keguruan. 7(14). 79-80

Basrowi. (2015). Pengantar Sosiologi. Bogor: Ghalia Indonesia.

Bimo Walgito. (2007). Psikologi Kelompok. Yogyakarta: Andi Offset

Creswell, J. W. (2010). Pendekatan Kualitatif, Kuantitatif, dan Mixed. Yogyakarta: PT Pustaka Pelajar.

Darmadi, Hamid. (2013). Metode Penelitian Pendidikan dan Sosial. Bandung: Alfabeta.

Hadi. (2009). Biologi Insecta Entomologi.Yogyakarta: Graha Ilmu.

Hardywinoto. (2005). Menjaga Keseimbangan Kualitas Hidup Para Lanjut Usia. Jakarta : Gramedia Pustaka Utama.

Moleong, Lexy J. (2010). Metodologi Penelitian Kualitatif. Bandung: PT Remaja Rosdakarya.

Moleong, Lexy J. (2017). Metodologi Penelitian Kualitatif. Bandung: PT Remaja Rosdakarya.

Prasanti Ditha. (2016). Perubahan media komunikasi dalam pola komunikasi keluarga di era digital. Jurnal Commed. 1(1). 70-71

Riviani, dkk. (2014). Perbedaan Permasalahan Lansia yang Tinggal di Panti Jompo. Retrieved Maret 11, 2019, from Academia.edu 
https://www.academia.edu/9364924/perbedaan_permasalahan_lansia_yang tinggal_di_panti_jompo_dengan_lansia_yang_tinggal_dengan_keluarga Uma Sekaran. (2011). Metode Penelitian Untuk Bisnis. Jakarta: Salemba Empat. Yin, Robert K. (2011). Desain dan Metode. Jakarta: Rajagrafindo Persada. 